\title{
PLEASE (Pick, List, Evaluate, Activate, Supply, and End) Strategy Toward Student's Writing Achievement on Recount Text
}

\author{
Ni'matul Farikhah \\ SMA Pangudi Luhur Sukaraja \\ farikhahnikmatul@gmail.com
}

\begin{abstract}
The thesis entitled "The Influence of Using PLEASE (Pick, List, Evaluate, Activate, Supply And End) Strategy Toward Student's Writing Achievement on Recount Text at The Tenth Grade of SMA Pangudi Luhur Sukaraja". The problem of this study as follows "Is there any significant differences between the students who are taught by using the PLEASE strategy and who are not taught by using the PLEASE strategy toward student's writing achievement on recount text at the tenth grade of SMA Pangudi Luhur Sukaraja?". In this study, the writer used a quasi-experimental design. The population in this study was the tenth-grade students of SMA Pangudi Luhur Sukaraja, with the total of the population was 64 students. Whereas, the sample of the study was 40 students were taken by using purposive sampling, those were 20 students of XIPS ${ }^{1}$ as experimental group and 20 students of XIPS ${ }^{2}$ as the control group. Moreover, the writer used a written test. The data obtained from Independentt-test analysis, between the result of the post-test in experimental class and control class. Based on the calculation by using an Independent $t$-test, the researcher found that tobtained was higher than $t_{\text {table }}(6.211>1.697)$ at the significance level $a=0.05$ in a two-tailed test. So, the Null Hypothesis ( $\mathrm{HO}$ ) was rejected and the Alternative Hypothesis $(\mathrm{Ha})$ was accepted. It can be concluded that there was any significant difference in teaching writing by using PLEASE Strategy in SMA Pangudi Luhur.
\end{abstract}

Keywords: Teaching , Writing, and PLEASE Strategy

\section{INTRODUCTION}

English is taught as a foreign language $(E F L)$ in which it exists in the curriculum from elementary to senior high school in Indonesia. It needs to be underlined that one important thing in English is to communicate in a global community. To communicate successfully and effectively, four language skills need to be mastered, namely: listening, reading, speaking, and writing. Everybody has to know and learn about four skills in English if they want to be masters in English. Moreover, Esberger (2010) states that there are four skills consist of two inputs as listening and reading, and two output as speaking and writing. In the English program, these integrated skills as the base of study, cannot be separated. By listening or reading, the listener would likely able to speak or write in English. Therefore, learners need to understand four skills to be good in English. As one of four basic skills in mastering English, writing is an important skill that needs to be practiced.

As a state of Clark (2007:4), writing is a student's instrumentation of thinking that allows students to express their thoughts by word. Through selecting and arranging language, the students come to understand how language is used. As a result, the students can express their ideas, feelings, opinions through writing practice. According to Megaiab (2014) in WEI International Academic Conference Proceedings in Bali, Indonesia showed that learners' English writing competence was encountered problems in many categories. The problems were mostly in grammar such as tenses, articles, singular and plural, verbs, prepositions, and spelling. Moreover, the learners face some difficulties in the punctuation and capitalization. Most of these errors were encountered as a result of the mother tongue influence. A total of 1654 grammatical errors were found. It can be concluded that the weakest area in writing English by Indonesian learners of English as a foreign language was in the grammatical aspects.

Based on the writer's experience in practice teaching at Senior High School of Pangudi Luhur Sukaraja, the writer found that some of the problems that were from the students and the teacher. 
Firstly, the students were difficult to write a recount text. Next, they did not know what they want to write. Because the students were difficult to think about the ideas about the topic and arrange the ideas. They were also difficult to activate a topic paragraph with a topic sentence. Then, they were still confused to make the sentences or paragraphs coherence to each other. In the teacher's problem, the teacher was less accurate to give the strategy that had to teach the students in written form.

Eacott (2007) stated that a strategy is a set of established practices to reach determine expectations. He adds the determine expectations referred to the purpose of the teaching process while the establishing practices referred to the progressive activities which engaged the students in the teaching process. In other words, the use of strategy created an opportunity for the teacher to facilitated the students to apply what they learn in the classroom to real-life experiences.

The way to solve the student's difficulties in writing achievement the writer used the PLEASE (Pick, List, Evaluate, Activate, Supply, and End) Strategy. PLEASE Strategy is one of the mnemonic strategies that provided students with a roadmap to write a paragraph. Boyle and Scanlon (2010:246) stated that PLEASE is a mnemonic writing strategy that guides the students to write all of the parts of a paragraph using planning, composing and revising components. This strategy can help students to generate their ideas and guide them while writing. It can be concluded that the PLEASE strategy can solve a student's writing problem especially in writing a paragraph. This strategy helps students to start writing and help them to write step by step until they finish writing recount text. In applying the PLEASE strategy, students had to know who will read their writing and select appropriate topics and begin collecting data or information about what they will write and start writing them. This strategy can be used not only in writing recount text but also in essays.

The "PLEASE" strategy is a mnemonic that provides learners with a road map for writing a paragraph (Welch, 1992). It reminds learners to carry out several steps for writing paragraphs. Welch (1992) assumes the PLEASE strategy is used as a management strategy in solving problems in writing paragraphs. According to Peha (2003:3), PLEASE Strategy is included in prewriting activity. As the explanation in steps of writing, prewriting is the first activity in writing. Peha states: "Pre-writing is any activity that helps writers figure out what to write about. Many things quality as prewriting activities."

The advantages of using PLEASE strategy helped students generate, organize, and to write sentences and paragraph, help the students remember and apply activities involve in the process of planning and writing, It is suitable for all of genres/kinds of paragraph, PLEASE strategy can help the students to improve the students' writing ability especially in writing a paragraph and also in a text.

\section{METHODOLOGY}

The type of this research is quantitative. Meanwhile, the method used in this research was experimental research. Sugiyono (2015:107) defined that experimental research is research that is used to find the effect of certain treatment against others in controlled conditions. Cohen, Manion, and Morrison (2007:274) divided the experimental design into three types: true experimental design, quasi-experimental design, and natural experimental design. According to Sugiyono (2015:114), quasi-experimental design there are two forms of time series design and nonequivalent control group design. The design used in this research was quasi-experimental for nonequivalent control group design. Before treatment, both the experimental group and the control group gave a pretest test, intending to know the condition of the group. Then after treatment, the experimental group and the control group gave a posttest test, to determine the condition of the group. The first group was given a treatment and the other group was not given a treatment. The group which was given a treatment that was an experimental group, and the group which was not given a treatment that was a control group. Firstly, each of the groups receive a pre-test, and then only the experiment class was authored by the researcher. After the treatment, each group was given a post-test.

In this study, there were two variables: an independent variable and a dependent variable. 
In this research, the independent variable was PLEASE Strategy and student's writing achievement as the dependent variable. The population of this research was the tenth-grade students of SMA Pangudi Luhur Sukaraja Academic year 2018/2019. It had 3 classes which consist of 1 class for natural science, and 2 classes for social science. The number of the tenth-grade students of SMA Pangudi Luhur Sukaraja Academic year 2018/2019 was (64) students. The writer choose two classes as a sample for the experimental class and control class. X IPS ${ }^{1}$ as an experimental class that the number of students was 20 students. X IPS ${ }^{2}$ as a control class that the number of students was 20 students. This research used purposive sampling.

For collecting the data, the writer used the test. And there are two kinds of tests in this study: the pretest and the posttest. The pretest will be given before the experimental and the posttest will be given after the treatment to know the development of student's reading achievement. And for the test as the instrument, it is measured by content validity (test specification). Moreover, To find out the reliability of the test items, the writer did the try out to other students (nonsampling). Dealing with it, Fraenkel and Wallen (2012) stated that for research purposes, a useful rule was that reliability should be at least 0.70 or preferably higher. The result of the reliability was 0.93 . So, it could be concluded that the test items were reliable.

\section{RESULT AND DISCUSSION}

In this section, the writer presents the findings of the study that was already done. Findings highlight the result normality, homogeneity, and hypothesis that were taken during the research. The result of this research based on the findings showed that teaching writing recount text by using PLEASE Strategy was a significant influence. To find out whether or not there was any significant difference in writing ability, the writer The type of this research is quantitative. Meanwhile, the method used in this research was experimental research. Sugiyono (2015:107) defined that experimental research is research that is used to find the effect of certain treatment against others in controlled conditions. Cohen, Manion, and Morrison (2007:274) divided the experimental design into three types: true experimental design, quasi-experimental design, and natural experimental design. According to Sugiyono (2015:114), quasi-experimental design there are two forms of time series design and nonequivalent control group design. The design used in this research was quasi-experimental for nonequivalent control group design. Before treatment, both the experimental group and the control group gave a pretest test, intending to know the condition of the group. Then after treatment, the experimental group and the control group gave a posttest test, to determine the condition of the group. The first group was given a treatment and the other group was not given a treatment. The group which was given a treatment that was an experimental group, and the group which was not given a treatment that was a control group. Firstly, each of the groups receive a pre-test, and then only the experiment class was authored by the researcher. After the treatment, each group was given a post-test.

In this study, there were two variables: an independent variable and a dependent variable. In this research, the independent variable was PLEASE Strategy and student's writing achievement as the dependent variable. The population of this research was the tenth-grade students of SMA Pangudi Luhur Sukaraja Academic year 2018/2019. It had 3 classes which consist of 1 class for natural science, and 2 classes for social science. The number of the tenth-grade students of SMA Pangudi Luhur Sukaraja Academic year 2018/2019 was (64) students. The writer choose two classes as a sample for the experimental class and control class. X IPS ${ }^{1}$ as an experimental class that the number of students was 20 students. X IPS ${ }^{2}$ as a control class that the number of students was 20 students. This research used purposive sampling.

For collecting the data, the writer used the test. And there are two kinds of tests in this study: the pretest and the posttest. The pretest will be given before the experimental and the posttest will be given after the treatment to know the development of student's reading achievement. And for the test 
as the instrument, it is measured by content validity (test specification). Moreover, To find out the reliability of the test items, the writer did the try out to other students (nonsampling). Dealing with it, Fraenkel and Wallen (2012) stated that for research purposes, a useful rule was that reliability should be at least 0.70 or preferably higher. The result of the reliability was 0.93 . So, it could be concluded that the test items were reliable.

compared the result of the post-test in the control group and experimental group by using an independent sample t-test. The result of the SPSS 16 calculation was described as follow:

Table 1

Independent Sample t-test

\begin{tabular}{|c|c|c|c|c|c|c|c|c|c|c|}
\hline & \multicolumn{2}{|c|}{$\begin{array}{l}\text { Levene's Test } \\
\text { for Equality of } \\
\text { Variances }\end{array}$} & \multicolumn{7}{|c|}{ t-test for Equality of Means } \\
\hline & & \multirow[t]{2}{*}{$\bar{F}$} & \multirow[t]{2}{*}{ Sig. } & \multirow[t]{2}{*}{$\mathbf{t}$} & \multirow[t]{2}{*}{$\overline{D f}$} & \multirow{2}{*}{$\begin{array}{l}\text { Sig. } \\
(2- \\
\text { taile } \\
\text { d) }\end{array}$} & \multirow[t]{2}{*}{$\begin{array}{c}\text { Mean } \\
\text { Differen } \\
\text { ce }\end{array}$} & \multirow{2}{*}{$\begin{array}{c}\text { Std. } \\
\text { Error } \\
\text { Differenc } \\
\text { e }\end{array}$} & \multicolumn{2}{|c|}{$\begin{array}{l}\text { 95\% Confidence } \\
\text { Interval of the } \\
\text { Difference }\end{array}$} \\
\hline & & & & & & & & & Lower & Upper \\
\hline \multirow[t]{2}{*}{ Score } & $\begin{array}{l}\text { Equal variances } \\
\text { assumed }\end{array}$ & 3.429 & .072 & 6.211 & 38 & .000 & 18.469 & 2.973 & 12.450 & 24.488 \\
\hline & $\begin{array}{l}\text { Equal variances } \\
\text { not assumed }\end{array}$ & & & 6.211 & 32.260 & .000 & 18.469 & 2.973 & 12.414 & 24.524 \\
\hline
\end{tabular}

Based on the score of t-obt gathered from SPSS 16, it shows that tobtained was higher than table $(6.211>1.697)$ at the significance level $a=0.05$ in two-tailed test with df was $(n-2)=(40-2)=38$. Therefore, the Null Hypothesis $(\mathrm{HO})$ was rejected and the Alternative Hypothesis $(\mathrm{Ha})$ was accepted. It meant that there was any significant difference between students who were taught by using PLEASE (Pick, List, Evaluate, Activate, Supply and End) Strategy and students who were not taught by using PLEASE (Pick, List, Evaluate, Activate, Supply and End) Strategy.

\section{CONCLUSION}

Based on the analysis of the findings and discussions, it was found that the result of the Independent Sample t-test of the post-test score in the experimental and control class gave the value of t-obtained was 6.211 and the value of Sig (2-tailed) was 0.000 . it meant that the value of t-obtained was higher than $\mathrm{t}$-table $=1.697$ with df was $(n-2)=(40-2)=38$, and value of Sig (2-tailed) was less than the value of Significance level $(a=0.05)$. So, the Null Hypothesis was rejected and the Alternative Hypothesis $(\mathrm{Ha})$ was accepted. It can be concluded there was any significant difference between students who were taught by using PLEASE Strategy and students who were not taught by using PLEASE Strategy.

\section{REFERENCIES}

Clark, S. K. (2007). Writing strategies for science. Huntington Beach: Shell Education.

Megaiab, Machalla. M. A. (2014). WEI International academic conference proceedings. The first Senior High School Bali.

Eacott, S. (2007). Strategy and The School Principal. Journal of Catholic School Studies,79(2), 3-18.

Boyle, J., \& Scanlon, D. (2010). Methods and strategies for teaching students with mild disabilities. Wadsworth: Cencage Learning.

Welch, M. (1992). The PLEASE strategy: A metacognitive learning strategy for improving the paragraph witing of students with mild disabilities. Learning disabilities quarterly, 15, 119128.

Peha, S. The writing teacher's guide. Teaching That Makes Sense, inc., 2003.p.3 
60 | Channing: English Language Education and Literature Vol. 4 No. 2 April 2019 Halaman: 56-60

Sugiyono. (2015). Metode penelitian pendidikan: pendekatan kuantitatif, kualitatif, dan $R \& D$. Bandung: Alfabeta.

Cohen, L., Manion, L., \& Morrison, K. (2007). Research methods in education. New York: Routledge Tailor \& Francis Group.

Fraenkel, J. R., Wallen, N. E., \& Hyun, H. H. (2012). How to design and evaluate research in education (8th Ed.). New York, NY: Mcgraw Hill Companies. 